\title{
Genetic Diversity of Watermelon mosaic virus in Slovakia and Iran Shows Distinct Pattern
}

Miroslav Glasa, Institute of Virology, Slovak Academy of Sciences, Bratislava, Slovakia; Kaveh Bananej, Plant Virus Research Department, Iranian Research Institute of Plant Protection (IRIPP), Tehran, Iran; Lukáš Predajňa, Institute of Virology, Slovak Academy of Sciences, Bratislava, Slovakia; and Aisan Vahdat, IRIPP, Tehran, Iran

\begin{abstract}
Glasa, M., Bananej, K., Predajňa, L., and Vahdat, A. 2011. Genetic diversity of Watermelon mosaic virus in Slovakia and Iran shows distinct pattern. Plant Dis. 95:38-42.

Although Watermelon mosaic virus (WMV) is one of the main cucurbit pathogens and has a worldwide distribution, reliable data on its molecular variability is still limited to some geographical regions. The genetic diversity of $36 \mathrm{WMV}$ isolates from Slovakia and Iran were studied by sequence analysis targeting two opposite genomic regions (P1 and NIb-CP). Phylogenetic analysis using partial sequences of the P1 gene showed that Slovak WMV isolates had greater diversity, representing two groups (group 1 and group 2), whereas all Iranian isolates belonged to a single group (group 2), with relatively low divergeance. Interestingly, in the NIb-CP region, all analyzed Slovak

and Iranian isolates clustered within the group 1, thereby illustrating the phylogenetic discrepancies between the two analyzed genomic regions. Based on these data, one-half of analyzed Slovak isolates and all Iranian WMV isolates showed a switch in affiliation based on considered genomic region, clearly indicating their recombinant nature. This work provides further evidence of the significant contribution of recombination to the evolutionary history of WMV and outlines the necessity to target more than a single genome fragment for accurate typing of WMV isolates.
\end{abstract}

Watermelon mosaic virus (WMV, genus Potyvirus, family Potyviridae) is widespread in cucurbit crops, mostly in temperate and Mediterranean climatic regions of the world (11). Similarly to other Potyvirus spp., WMV has a positive single-stranded RNA genome of approximately $10 \mathrm{~kb}$ in length encoding one large polyprotein, which is cleaved to yield at least 10 mature proteins by virus-encoded proteases (5). The virus is nonpersistently transmitted by several aphid species and can cause economically important diseases resulting in quality and yield losses. WMV has also been found in mixed infection with other viruses (e.g., Cucumber mosaic virus [CMV]) that produce a more severe disease than either virus alone $(10,14)$.

Sequence analysis based on the NIb-CP region revealed an important variability of WMV, with three distinct molecular groups. From those, group 1 is predominant and considered to contain the "classical" isolates. Group 2 isolates originate from different parts of the world and represent distinct molecular lineage. However, no particular biological traits should be associated with this group. Isolates of group 3 of different geographical origin were recently found in the southeastern part of France and were frequently associated with severe symptoms (thus called "emerging"; 3,4). Moreover, considerable genetic variation in WMV isolates has been observed due to genetic drift and frequent recombination events $(3,6,9,13)$.

Cucurbits are major vegetable crops in Iran, ranking first in economic value, second in yield, and third in planted acreage (8). In Iran, WMV was first reported in 1974 (7) and has subsequently reached a wide distribution in four cucurbit species (melon, cucumber, squash, and watermelon) in all major cucurbit-growing regions of Iran (1). The complete genome sequence of an Iranian

Corresponding author: M. Glasa, E-mail: Miroslav.Glasa@ savba.sk

M. Glasa and K. Bananej contributed equally to this work.

Accepted for publication 10 September 2010.

doi:10.1094/PDIS-05-10-0355

(C) 2011 The American Phytopathological Society isolate has been determined (5). Partial nucleotide sequences of some Iranian WMV isolates of the coat protein (CP) gene (16) have been determined subsequently.

The cucurbit production in Slovakia remains only marginal and cucurbit plants are mainly cultivated in private gardens. The presence of WMV in Slovakia was discovered in the 1960s (15) but without further investigation.

Analysis of genetic diversity and the understanding of the relationships between viral strains or isolates is an important aspect in the management of viral diseases and the risk of emerging new viruses. WMV is considered one of the most important cucurbit pathogens worldwide; however, the scarcity of information on its molecular variability from some geographical areas can limit the real understanding of the complexity of this virus. In this study, we have determined the partial sequences of WMV isolates in Slovakia and Iran to asses their molecular variability and compare them with WMV isolates previously reported from around the world.

\section{Materials and Methods}

Virus isolates. Thirty-six WMV isolates were obtained from naturally infected squash (Cucurbita pepo L.), zucchini (C. pepo L.), melon (Cucumis melo L.), and cucumber (C. sativus L.) plants from 2004 to 2008 in distinct locations in Slovakia and Iran (Table 1). The leaf samples were tested for WMV by double-antibody sandwich enzyme-linked immunosorbent assay (DAS-ELISA) as described (2) using polyclonal antibodies kindly provided by Dr. H. Lecoq (INRA Avignon, France). All field samples were tested in parallel to detect the presence of other common cucurbit virusesCMV, Zucchini yellow mosaic virus (ZYMV), Cucumber aphidborne yellows virus (CABYV), Papaya ringspot virus (PRSV), and Squash mosaic virus (SqMV)—using polyclonal antibodies from INRA Avignon (France).

Reverse-transcriptase polymerase chain reaction and sequence analyses. Total RNAs were extracted using the RNeasy Plant Mini Kit (Qiagen) or TRI-Reagent (Sigma-Aldrich) directly from leaves of original infected cucurbit field plants. A two-step reverse-transcriptase polymerase chain reaction (RT-PCR) protocol was systematically followed. The first-strand cDNA was synthesized by reverse transcription of total RNA using random hexamer 
primers and the Avian myeloblastosis virus (AMV) reverse transcriptase (Promega Corp.). Subsequent PCRs were performed from the same RT preparation to amplify both targeted genomic portions. A cDNA fragment spanning a 574-bp major part of the P1 coding region was amplified using primers WMV354F $5^{\prime}$ GAG ACCTTAGTGCATCAGGAG $3^{\prime}$ and WMV926R 5' GCTTGC TGTTCATACTTGCC 3', corresponding to nucleotides 353 to 926 (nucleotide positions are determined from the full-length sequence of the WMV-Fr isolate, AY437609). Due to difficulties in amplification of Iranian isolates, the primers were adapted based on complete genome sequence of Iranian isolate EU660584 as follows (changes are underlined): WMV354F_IR 5' GAGACCTㅡA ATGCATCAGGAG $3^{\prime}$ and WMV926R_IR $5^{\prime}$ GCECTGCTGT TCATACTTACC $3{ }^{\prime}$. Additionally, the region of approximately 400 bp overlapping the end of the NIb and N-terminal part of the CP was amplified using the primers WMV-5/WMV-3 described by Desbiez et al. (3). PCR amplifications were performed using the proofreading TaKaRa Ex Taq polymerase (Takara Bio Inc.) and under the following cycling conditions for both regions: initial denaturation at $94^{\circ} \mathrm{C}$ for $5 \mathrm{~min} ; 35$ cycles of $94^{\circ} \mathrm{C}$ for $1 \mathrm{~min}, 54^{\circ} \mathrm{C}$ for $45 \mathrm{~s}$, and $72^{\circ} \mathrm{C}$ for $1 \mathrm{~min}$; followed by a final extension step at $72^{\circ} \mathrm{C}$ for $10 \mathrm{~min}$. The RT-PCR products were purified using Wizard PCR Preps DNA Purification System (Promega Corp.) and sequenced directly from both directions by priming the sequencing reaction with the same oligonucleotides as used for PCR in order to obtain a master (dominant) sequence of isolate.

Partial sequences were compared with the sequences available in the GenBank database (www.ncbi.nlm.nih.gov). Sequence analyses were performed using the ClustalX program (18) and the Molecular Evolutionary Genetics Analysis (MEGA v.4.1) software (17).
The phylogenetic tree was inferred using the neighbor-joining algorithm implemented in MEGA. Kimura's two-parameter method and a p-distance model were applied for nucleotide and amino acid sequence analyses, respectively.

Nucleotide sequence accession numbers. The nucleotide sequences of Slovak WMV isolates reported in this paper have been deposited in the GenBank database under accession numbers FJ754333 to FJ754348, GQ241689 to GQ241695, and GQ241604 to GQ241616 and those of Iranian WMV isolates under accession numbers FJ754326 to FJ754332, FJ754349 to FJ754354, and GQ241696 to GQ241703.

\section{Results and Discussion}

A better knowledge of virus genetic diversity and mapping of virus populations enables us to understand the epidemiological complexity of the pathogen. In this work, the partial sequences of 36 WMV isolates from various cucurbit hosts (squash, melon, cucumber, zucchini, and cantaloupe) from Slovakia (collected in 2003 to 2008) and Iran (collected in 2006 to 2008) were determined with an aim to study their diversity. Due to the frequent recombination events determined for WMV, with different cross-overs mostly located between the C-terminal half of the HC-Pro coding region and the N-terminal part of the CI coding region (6), the typing of isolates based on only a single genome fragment may not accurately represent the evolutionary history of isolates. Therefore, our analysis targeted two opposite and substantially informative genomic regions (i.e., NIb-CP and P1). The N-terminal part of $\mathrm{CP}$ represents a highly variable region frequently used in molecular analysis of Potyvirus spp. (19). An ancestral interspecies recombination event has previously been detected in the P1

Table 1. Watermelon mosaic virus isolates analyzed in this study

\begin{tabular}{|c|c|c|c|c|c|c|c|}
\hline Isolate & Country & Locality & Year & $\begin{array}{l}\text { Original } \\
\text { host }\end{array}$ & $\begin{array}{l}\text { Accession no. } \\
\text { (P1) }\end{array}$ & $\begin{array}{c}\text { Accession no. } \\
(\mathbf{N I b}-\mathbf{C P})^{\mathrm{a}}\end{array}$ & $\begin{array}{l}\text { Molecular type } \\
\quad(\text { P1-CP) }\end{array}$ \\
\hline SK01-sq & Slovakia & Senkvice & 2004 & Squash & FJ754333 & n.d. & $\ldots$ \\
\hline SK02-sq & Slovakia & Senkvice & 2004 & Squash & FJ754335 & GQ241610 & $1-1$ \\
\hline SK03-sq & Slovakia & Modra & 2004 & Squash & FJ754336 & n.d. & $\ldots$ \\
\hline SK04-me & Slovakia & Bratislava & 2005 & Melon & FJ754337 & n.d. & $\ldots$ \\
\hline SK05-zu & Slovakia & Cifer & 2006 & Zucchini & FJ754341 & n.d. & $\ldots$ \\
\hline SK06-sq & Slovakia & Cifer & 2007 & Squash & FJ754342 & n.d. & $\ldots$ \\
\hline SK07-zu & Slovakia & Pezinok & 2008 & Zucchini & FJ754343 & GQ241604 & $2-1$ \\
\hline SK08-zu & Slovakia & Pezinok & 2008 & Zucchini & FJ754344 & GQ241612 & $2-1$ \\
\hline SK09-zu & Slovakia & Pezinok & 2008 & Zucchini & FJ754345 & n.d. & $\ldots$ \\
\hline SK10-me & Slovakia & Dunajska Streda & 2008 & Melon & FJ754334 & GQ241613 & $1-1$ \\
\hline SK11-cc & Slovakia & Dunajska Streda & 2008 & Cucumber & FJ754339 & n.d. & $\ldots$ \\
\hline SK12-zu & Slovakia & Trnava & 2008 & Zucchini & FJ754340 & n.d. & $\ldots$ \\
\hline SK13-zu & Slovakia & Martin & 2008 & Zucchini & FJ754346 & n.d. & $\ldots$ \\
\hline SK14-sq & Slovakia & Bratislava & 2008 & Squash & FJ754347 & n.d. & $\ldots$ \\
\hline SK15-sq & Slovakia & Podkylava & 2008 & Squash & FJ754348 & GQ241605 & $2-1$ \\
\hline SK16-sq & Slovakia & Topolcany & 2008 & Squash & FJ754338 & GQ241609 & $1-1$ \\
\hline SK17-sq & Slovakia & Podkylava & 2008 & Squash & GQ241689 & GQ241606 & $2-1$ \\
\hline SK18-zu & Slovakia & Cifer & 2006 & Zucchini & GQ241692 & GQ241614 & $1-1$ \\
\hline SK19-sq & Slovakia & Senkvice & 2003 & Squash & GQ241694 & GQ241615 & $1-1$ \\
\hline SK20-sq & Slovakia & Senkvice & 2005 & Squash & GQ241695 & GQ241616 & $1-1$ \\
\hline SK21-zu & Slovakia & Cifer & 2005 & Zucchini & GQ241693 & GQ241611 & $1-1$ \\
\hline SK22-cu & Slovakia & Cifer & 2005 & Cucumber & GQ241690 & GQ241607 & $2-1$ \\
\hline SK23-zu & Slovakia & Cifer & 2005 & Zucchini & GQ241691 & GQ241608 & $2-1$ \\
\hline IR01-sq & Iran & Semnan/Eivankey & 2008 & Squash & FJ754326 & GQ241696 & $2-1$ \\
\hline IR02-sq & Iran & Hamedan/Bahar & 2008 & Squash & FJ754331 & GQ241700 & $2-1$ \\
\hline IR03-sq & Iran & East-Azerbaijan/Bonab & 2006 & Squash & FJ754332 & GQ241701 & $2-1$ \\
\hline IR04-me & Iran & Markazi/Mahallat & 2008 & Melon & FJ754353 & n.d. & $\ldots$ \\
\hline IR05-sq & Iran & Khorasan/Mashad & 2008 & Squash & FJ754352 & n.d. & $\ldots$ \\
\hline IR06-me & Iran & Tehran/Pakdasht & 2008 & Melon & FJ754329 & GQ241702 & $2-1$ \\
\hline IR10-me & Iran & Guilan/Somesara & 2007 & Melon & FJ754349 & GQ241703 & $2-1$ \\
\hline IR11-cu & Iran & Ghazvin/Eghbalieh & 2008 & Cucumber & FJ754330 & GQ241699 & $2-1$ \\
\hline IR12-cu & Iran & Guilan/Roodbar & 2007 & Cucumber & FJ754350 & n.d. & $\ldots$ \\
\hline IR15-me & Iran & Semnan/Garmsar & 2008 & Melon & FJ754351 & n.d. & $\ldots$ \\
\hline IR16-sq & Iran & Markazi/Delijan & 2008 & Squash & FJ754328 & GQ241698 & $2-1$ \\
\hline IR17-ca & Iran & Khorasan/Taibad & 2008 & Cantaloupe & FJ754327 & GQ241697 & $2-1$ \\
\hline IR18-sq & Iran & East-Azerbaijan/Mianeh & 2006 & Squash & FJ754354 & n.d. & $\ldots$ \\
\hline
\end{tabular}

a Abbreviation: n.d. = not determined.

$\mathrm{b}$ If the sequences of both genomic region are available, based on Desbiez and Lecoq (6). 
protein, suggesting that WMV has emerged through an ancestral interspecific recombination event affecting the $5^{\prime}$ part of the genome (5).

Phylogenetic analysis using nucleotide sequences of the P1 gene showed that WMV isolates determined in this study and previously characterized WMV isolates retrieved from the public database $(n$ $=105$ ) divided into three phylogenetic groups unambiguously defined with a high bootstrap support: group 1 (classical isolates), group 2, and group 3 (emerging isolates [EM]), as previously described (3,4; Fig. 1).

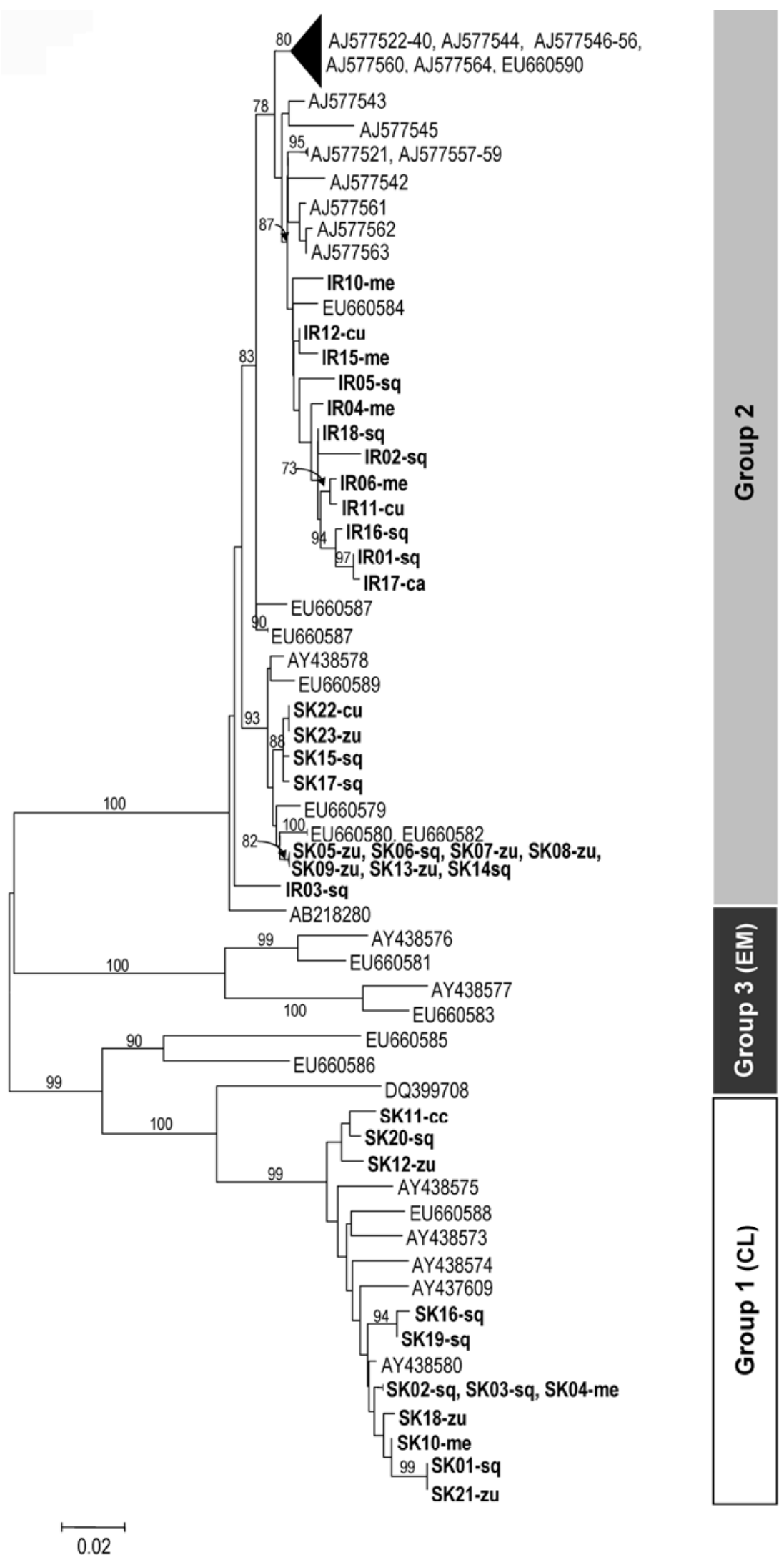

Fig. 1. Neighbor-joining tree of 105 Watermelon mosaic virus isolates, generated from partial nucleotide sequences coding for $\mathrm{P} 1$ protein (the isolates analyzed in this work are in bold). $\mathrm{EM}=$ emerging and $\mathrm{CL}=$ classical isolates. Scale bar indicates a genetic distance of 0.02 . Bootstrap values $>70$ (1,000 bootstrap resamplings $)$ are indicated as percentages 
The Slovak WMV isolates clustered in two groups (group 1 and group 2), without clear geographical structure. The mean nucleotide intragroup divergence in the analyzed $\mathrm{P} 1$ region was 0.016 and 0.05 for Slovak WMV isolates of group 1 and group 2, respectively. Mean distance between these isolate groups reached 0.199. Overall divergence, including all 23 analyzed Slovak isolates, was $0.110( \pm 0.011)$.

In contrast, except for the IR-03sq isolate clustering slightly away but still in group 2, all Iranian WMV isolates showed very close relatedness, forming a compact cluster together with previously sequenced Iranian isolate EU660584 (Fig. 1). Overall mean value of Iranian population was $0.022( \pm 0.003)$. The divergent IR-03sq isolate has shown 93.0 to $95.0 \%$ sequence identity with the remaining Iranian isolates (calculated divergence between IR-03sq and other Iranian isolates reached 0.041). No isolate belonging to the EM group (4) has been found in both countries.

Based on the McDonald and Kreitman neutrality test implemented in the DnaSP (Rozas et al. 2003), the analyzed P1 genomic region looks to be selectively neutral $(\mathrm{NI}=1.13, \alpha$ value $=-0.13$ ). No mutation has been highlighted to follow positive selection, and observed variability in Slovak and Iranian isolates appears to be due to random genetic drift.

In order to extend the analysis of genetic diversity, WMV isolates from Slovakia and Iran were sequenced in the opposite genomic region, spanning the end of the $\mathrm{NIb}$ and $\mathrm{N}$-terminal part of the CP. Due to the technical problems linked to the unavailability of material of some isolates, only 21 of 36 isolates could be analyzed in this genomic portion. In the NIb-CP analyzed region, the average sequence divergence was very low. For Slovak isolates, it reached $0.011( \pm 0.003)$ and $0.008( \pm 0.003)$ at the nucleotide and amino acid level, respectively; and, for Iranian isolates, $0.017( \pm 0.004)$ and $0.015( \pm 0.007)$, respectively. All Slovak and Iranian isolates had a KEA motif in the beginning of $\mathrm{CP}$ (amino acids 3 to 5 of $\mathrm{CP}$ ), which is a characteristic feature for isolates of group 1 (3).

Interestingly, the phylogenetic analyses of the $\mathrm{NIb}-\mathrm{CP}$ region clustered all Slovak and Iranian isolates to group 1 (Fig. 2), showing the discrepancies in the affiliation of some isolates when compared with the P1 analysis alone. These results indicate that the genomes of all the analyzed Iranian WMV isolates and part of the Slovak isolates (clustering within group 2 in the P1 region) have arisen from recombination. There was, however, no correlation in terms of separate clustering of recombinant and classical isolates in the NIb-CP portion. This work provides further evidence of the significant contribution of recombination to the evolutionary history of plant viruses (9) and supports previous data on WMV genetic diversification (7).

Based on our results, two genetically different populations have been found to occur in Slovakia (i.e., classical isolates of group 1, with no detectable recombination [similar to WMV-Fr isolate AY437609] and a population of recombinant isolates [having a $5^{\prime}$ part of the genome similar to group 2 isolates and a $3^{\prime}$ part similar to group 1 isolates]).

The data indicate at least two independent introductions of WMV in Slovakia and further spread of virus via aphid transmission. The ratio of isolates belonging to genetically distinct WMV populations in Slovakia was roughly equal (Table 1, 7 versus 6), without clear-cut linking to host or year of isolation, and no specific biological feature (in terms of symptomatology or aggresiveness) should be associated with different WMV types. Moreover, in Slovakia, WMV has been detected by DAS-ELISA to commonly occur in tested cucurbit plants in double or multiple mixed infection with other viruses (ZYMV, WMV, CMV, or CABYV; data not shown), potentially complicating specific symptom evaluation. The easy exchange of biological material within the European market provides the possibility of the spread of different WMV variants within the area (12). Moreover, in Slovakia, cucurbits are often cultivated in private gardens or small field spots where virus dissemination remains uncontrolled. This

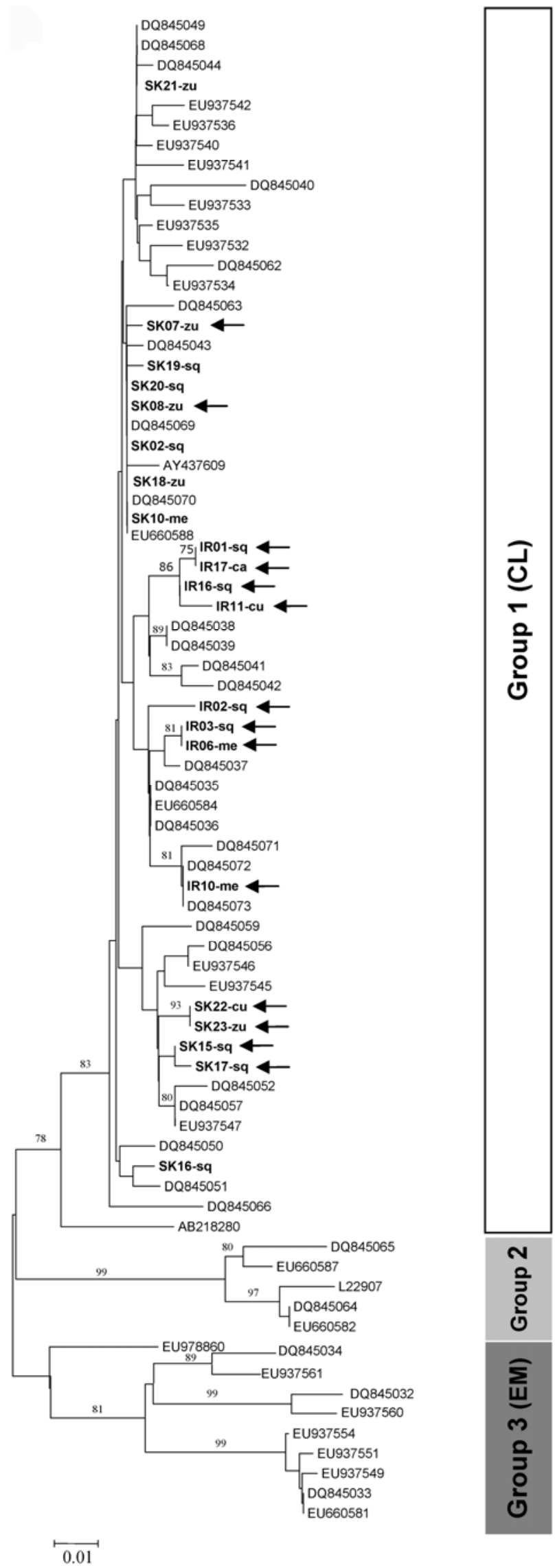

Fig. 2. Neighbor-joining tree obtained on a 272-bp Nlb-CP fragment of Watermelon mosaic virus isolates. Recombinant Slovak and Iranian isolates are indicated by an arrow. $\mathrm{EM}=$ emerging and $\mathrm{CL}=$ classical isolates. Scale bar indicates a genetic distance of 0.01 . Bootstrap values $>70$ ( 1,000 bootstrap resamplings) are indicated as percentages. 
should favor the diversification of the virus and can, in part, explain the higher diversity of WMV observed in Slovakia.

In contrast, during the survey in Iran, only relatively homogenous populations of recombinate group2/group1 isolates, similar to previously fully sequenced Iranian isolate EU660584, were detected. This is in agreement with a previous study of WMV variability in Iran (16), showing (except in one case) that all isolates should be classified in group 1 based on their CP sequences. However, as was shown here, the typing of virus isolates targeting a single genome fragment could not provide accurate results, especially with viruses that have undergone multiple recombination events in the evolutionary history, such as WMV. Thus, this work considerably expands on previous studies of WMV diversity in Iran. One may speculate that surprisingly low variation within WMV isolates collected over a 3-year sampling period in different major growing areas in Iran, a country where cucurbits represent one of the major cultivated crops, can imply either strong negative selection pressure, subjection to a severe bottleneck, or another unidentified constraint on virus variation.

\section{Acknowledgments}

This work was supported by grant no. 2/0030/10 from the Scientific Grant Agency of Ministry of Education of Slovak Republic and Slovak Academy of Sciences and a grant from the Iranian Research Institute of Plant Protection. We thank S. Gadiou for helpful discussion.

\section{Literature Cited}

1. Bananej, K., and Vahdat, A. 2008. Identification, distribution and incidence of viruses in field-grown cucurbit crops of Iran. Phytopathol. Mediterr. 47:247-257.

2. Clark, M. F., and Adams, A. N. 1977. Characteristics of microplate method of enzyme-linked immunosorbent assay for the detection of plant viruses. J. Gen. Virol. 34:475-483.

3. Desbiez, C., Costa, C., Wipf-Scheibel, C., Girard, M., and Lecoq, H. 2007. Serological and molecular variability of Watermelon mosaic virus (genus Potyvirus). Arch. Virol. 152:775-781.

4. Desbiez, C., Joannon, B., Wipf-Scheibel, C., Chandeysson, C., and Lecoq H. 2009. Emergence of new strains of Watermelon mosaic virus in Southeastern France: evidence for limited spread but rapid local population shift. Virus Res. 141:201-208.

5. Desbiez, C., and Lecoq, H. 2004. The nucleotide sequence of Watermelon mosaic virus (WMV, Potyvirus) reveals interspecific recombination between two related potyviruses in the 5' part of the genome. Arch. Virol. 149:1619 1632 .

6. Desbiez, C., and Lecoq, H. 2008. Evidence for multiple intraspecific recombinants in natural populations of Watermelon mosaic virus (WMV, Potyvirus). Arch. Virol. 153:1749-1754.

7. Ebrahim-Nesbat, F., 1974. Distribution of Watermelon mosaic viruses 1 and 2 in Iran. Phytopathol. Z. 79:352-358.

8. FAO. 1996. FAO Production Yearbook, Vol. 50. FAO Statistics Ser. No. 135 Food and Agriculture Organization of the United Nations, Rome.

9. Garcia-Arenal, F., Fraile, A., and Malpica, J.M. 2001. Variability and genetic structure of plant virus populations. Annu. Rev. Phytopathol. 39:157 186.

10. Lecoq, H. 1992. Les virus des cultures de melon et de courgette de plein champ (II), PHM. Rev. Hortic. 324:15-25.

11. Lecoq, H., and Desbiez, C. 2008. Watermelon mosaic virus and Zucchini yellow mosaic virus. Pages 433-440 in: Encyclopedia of Virology, Vol. 5 , 3rd ed. B. W. J. Mahy and M. H. V. Van Regenmortel, eds. Elsevier, Oxford.

12. Lecoq, L., Desbiez, C., Wipf-Scheibel, C., and Girard, M. 2003. Potential involvement of melon fruit in the long distance dissemination of cucurbit potyviruses. Plant Dis. 87:955-959.

13. Moreno, I. M., Malpica, J. M., Díaz-Pendón, J. A., Moriones, E., Fraile, A., and García-Arenal, F. 2004. Variability and genetic structure of the population of Watermelon mosaic virus infecting melon in Spain. Virology 318:451-460.

14. Purcifull, D. E., Hiebert, E., and Edwardson, J. R. 1984. Watermelon mosaic virus 2. CMI/AAB Description of Plant Viruses, No. 293. Commonwealth Mycological Institute, Kew, UK. http://www.dpvweb.net/dpv/ showdpv.php?dpvno=293.

15. Schmelzer, K., and Milicic, D. 1966. Zur Kenntnis der Verbreitung des Wassermelonenmosaik-Virus in Europa und seiner Fahigkeit zur Bildung von Zelleinschlußkörpern. Phytopathol. Z. 57:8-16.

16. Sharifi, M., Massumi, H., Heydarnejad, J., Hosseini Pour, A., Shaabanian, M., and Rahimian, H. 2008. Analysis of the biological and molecular variability of Watermelon mosaic virus isolates from Iran. Virus Genes 37:304313.

17. Tamura, K., Dudley, J., Nei, M., and Kumar, S. 2007. MEGA4: Molecular Evolutionary Genetics Analysis (MEGA) software version 4.0. Mol. Biol. Evol. 24:1596-1599.

18. Thompson, J. D., Gibson, T. J., Plewniak, F., Jeanmougin, F., and Higgins, D.G. 1997. The ClustalX windows interface: flexible strategies for multiple sequence alignment aided by quality analysis tools. Nucleic Acids Res. 24:4876-4882

19. Ward, C. W., McKern, N. M., Frenkel, M. J., and Shukla, D. D. 1992. Sequence data as the major criterion for potyvirus classification. Arch. Virol. (Suppl.) 5:283-297. 